Paedagogia Christiana

2/46 (2020) - ISSN 1505-6872

\title{
Editorial: Being Alone Together in Education
}

'Stay at home', 'isolation', 'distanced': we are all too familiar with these words lately. They seem to be symbols of the current pandemic time, a time tied to the experience of solitude. And now we are issuing the second special issue of Paedagogia Christiana to focus on being alone together in education: how we live and learn solitude, silence and loneliness within as well as beyond community. The first special issue was related to the Alone Together symposium held in the UK, and since then, a second symposium (Alone Together Again) has been held, hosted by the University of Szczecin. In light of the covid-19 pandemic, the event was held online, and that in itself illustrated the theme beautifully. Each participant was alone, in an office or, more often, at home, and yet brought together online. Many of us - including the symposium organisers - were surprised how effective an online symposium could be, not only with presentations and discussions, but 'chat rooms' by the side of the presentations, and other informal events. What was missing was physical togetherness, the messy reality of a conventional meeting. 'Messy' is an interesting word. Many Christian places of worship have made use of the popular 'Messy Church' movement (https://www.messychurch. org.uk/). That movement encourages all ages (especially children) to take part in church-based events that include creative activities and often also involve eating together. A 'mess' can refer to an untidy place (and being able to 'make a mess, in church' is part of the attraction of Messy Church events), but it also refers to a place to eat (the 'officers' mess' is the name given to the canteen for military officers). So being 'messy' means living, playing, and 
especially eating together. That mess is harder to achieve online, alone or together, but we tried our best to achieve it during the symposium and here, in this journal.

We are delighted, therefore, to introduce a 'messy' special issue of the journal. The statistician Kish (Kalton and Heeringa 2003) is reported as having said that - in the analysis of large statistical datasets - it is vital to 'keep the mess in as long as you can'. That is, do not settle for neat and pure outcomes, but keep exploring the mess. Buber expressed this even more poetically:

I am not concerned with the pure; I am concerned with the turbid, the repressed, the pedestrian, with toil and dull contraryness - and with the breakthrough. With the break-through and not with perfection. (Buber, 2002, p. 41.)

In this special issue, psychological, philosophical, theological and cultural disciplines are well represented, and there are other articles - beyond the Alone Together Again theme - on health and care, too. All the articles are educational, of course, both in the general sense of exploring how people learn and develop their 'personhood' through their lifespans (their 'breakthroughs', in Buber's terms), and in the specific sense, for several pieces, of referring to pedagogies and educational institutions. Ben Lazare Mijuskovic writes of loneliness as 'the universal drive in all human beings', but tempers this by describing the significance of empathy in generating intimacy and thereby overcoming loneliness. There is a mutuality in empathy and intimacy - a mutuality all too often ignored in more individualistic philosophy or psychology, and more often present in religious writers. Piotr Domeracki attacks the issue of philosophical individualism head-on, with his account of loneliness as a communal issue - to be tackled dialectically. The third of the solitude articles, by Gillian Simpson, explores ways of coming to understand religion, making use of autoethnography - not as the isolated contemplative activity described by Aristotle as the highest form of living, but as an engaged and communal methodology that can overcome the loneliness of research through cultivating dialogue with distant literatures and cultures, as well as with those living close to us.

Simpson's holistic approach to learning is complemented by the account of adolescent development by Sandra Bosacki and colleagues. This article describes how important solitude and silence are in the lives and emerging personhood of adolescents. The negative stereotype of the silent and lonely adolescent is misleading, as the use of withdrawal at that age is essential to 
the process of becoming (relatively) independent adults. A subtle 'messiness' is evident in the findings, and the research provides clues to further explorations of the experience of adolescence. And the silence that Bosacki describes of adolescence reappears in Torgeir Field's account of the silence that is central to the films of Ingmar Bergman.

In another part of the journal we present a set of articles related to, among others, religious education. Richard Rymarz's research addresses religious and secular influences on early career teachers in Australian Catholic schools; Monika Sztamborska writes about education for service in the pedagogical thoughts of St Ursula Ledóchowska, while Sylwia Zydek focuses on religious education in organisations established by that same Saint: the Eucharistic Crusade and the Sodality of Our Lady. Two more articles refer to situations which might be accompanied by the experience of loneliness. Beata Borowska-Beszta and Katarzyna Wasilewska-Ostrowska present secondary qualitative data research on the helplessness of the homeless males addicted to alcohol, whereas Małgorzata Fopka-Kowalczyk explains the significance of support and spiritual care provided to people with chronic diseases.

We are living in such difficult times, often longing to be with other people yet having to stay apart, but the collaboration represented by this issue of the journal is itself an example of hope. It is a messy hope, complex and untidy, yet one that, as editors, we hope helps nourish our academic and professional lives.

Julian Stern and Matgorzata Watejko

Lincoln and Szczecin, November 2020

\section{References}

Buber, M. (2002 [1965]). Between Man and Man. London: Routledge.

Kalton, G. \& Heeringa, S. (Eds.) (2003). Leslie Kish: Selected Papers. Hoboken, New Jersey: Wiley. 
